Portland State University

PDXScholar

7-31-2017

\title{
A Study of Diverse, Inquiry-based Science Education in Portland, Oregon
}

Alivia R. DeGagne

Portland State University

Follow this and additional works at: https://pdxscholar.library.pdx.edu/honorstheses

Let us know how access to this document benefits you.

\section{Recommended Citation}

DeGagne, Alivia R., "A Study of Diverse, Inquiry-based Science Education in Portland, Oregon" (2017).

University Honors Theses. Paper 465.

https://doi.org/10.15760/honors.465

This Thesis is brought to you for free and open access. It has been accepted for inclusion in University Honors Theses by an authorized administrator of PDXScholar. Please contact us if we can make this document more accessible: pdxscholar@pdx.edu. 
A Study of Diverse, Inquiry-based Science Education in Portland, Oregon

by

Alivia DeGagne

An undergraduate honors thesis submitted in partial fulfillment of the

requirements for the degree of

Bachelor of Science

in

University Honors

and

Arts and Letters

Thesis Adviser

Amy Larson

Portland State University 


\begin{abstract}
As a result of the imbalance of success among racially and ethnically diverse students within STEM education, science, technology, engineering, and mathematics education is being recontextualized. Scholars and educators alike are finding the benefit in supporting inquiry based methods within the scientific curriculum because they increase a student's science conceptualization. Three public elementary schools who lead in science education in Portland are analyzed and compared to two public elementary schools who do not who do not have a specific focus on STEM. The comparison is created to determine the impact of the STEM programs being implemented are particularly beneficial to the diverse student population and the students' success. For this study I review the actions teachers take to embrace science education, processes in which science is promoted, and what is engaging students is explored through literature and synthesized with what Portland Public schools is doing in Portland, Oregon. It is evident that Portland Public schools serves many racially and ethnically diverse students. The findings represent the disparities between students test scores in STEM schools and those that are not. The variable between the schools is the implementation of STEM programs and sheds light on results of applying these programs. However, this synthesis could lead to a further investigation through interviews and observation of how these schools, and many more in Portland, are contributing to creating a stronger STEM education for all students.
\end{abstract}




\section{Introduction}

Elementary education is a time where students between the ages five years to ten years learn about their community, themselves, and their world. However, our science education is limited and struggling to produce science competent students. According to Drew DeSilver (2017) at Pew Research Center, American student's test scores rank 24th in science and 39th in mathematics compared globally. Desilver's (2017) study was conducted among students internationally and shows that science education in the US is limited and struggling to produce science competent students in contrast to the rest of the global student population. In response, education in the US is evolving and is rapidly embracing STEM-based education and inquiry-based learning into schools. Scientific inquiry is the capacity to construct explanations of scientific content knowledge through scientific procedures and STEM education (Minner 2010). The focus of STEM, an abbreviation for science, technology, engineering, and math, is not a new concept to the education system and educators around the world. In the height of the 1950's, Russia launched Sputnik, the first satellite, into space and caused an uproar of criticism of the American educational system. Proving that the US educational system lagged in STEM programs compared to the Soviet's science education programs that ultimately launched of the first spacecraft. This launching caused the United States federal government to intervene in education programs of all levels, not only elementary education, to compete with the superior Soviet educational system. The US government's intervention with the American school system was focused specifically on creating an "elite generation" (Jolly, 2009). The push for creating an "elite generation" of scientists in the US caused an upward shift in education, ultimately creating 
rigorous science and mathematic standards along with opportunity for students to explore various STEM professions.

In our current STEM education system, American students are being taught rote facts and how to use them for specific problems. According to Carol Lloyd (2016) at GreatSchools.org, Students are not learning how to apply distinct math skills to various situations instead are just learning to follow a strict set of rules that are explicitly laid out in every equation. Lloyd (2016) mentions that American students are "taught [that math] is a set of facts, not a process." According to the New York Times (2014), American students are trained in "answer-getting" instead of problem solving. The process in which created the answer-getting dilemma was referred to as "I, We, You". This process consisted of teacher demonstration, group examples, and individual work. It is evident that answer-getting is not an effective way to teach. In reaction to the inefficiency of "I, We, You", Magdalene Lampert, a professor at the University of Michigan, found a more effective way of teaching math in which she referred to as "You,Y'all, We". In this "You, Y'all, We" technique, students solve alone, then the students would discuss in peer groups for the y'all portion of the lesson, and finally, the entire group would partake in the we segment of the lesson where the logistics of the procedure would be explained. The process of sense making aligns closely with inquiry-based learning because of the emphasis on student responsibility toward student learning. So what's the problem? Our students are burning out due to an inefficient system that does not teach students the creativity in math and science but a set of rules that lead to a destination that results in inability to apply math skills to various challenges outside of the small parameter of textbook equations (Lloyd, 2016). 
According to Daphne Minner (2010) in the Journal of Research in Science Teaching, scientific inquiry-based instruction and the resulting student outcomes create high interest in policy makers around the world. The interest generated by STEM and inquiry-based learning stems solely from the achievements gained from scientific inquiry (Minner, 2010). In creating high interest in education politicians, STEM education and careers have become an imperative strategy for creating a more globally competitive economy. These concepts are important to our education systems as the US has ranked low in the past and continues to underperform on standardized tests compared to most developed nations (DeSilver, 2017). In fact, Elizabeth Smithey and Julie Davis (2009) have shown that many teachers throughout the US are not embracing science in their classroom due to a lack of their personal coursework or experience in the field, resulting in a passive student body that does not engage in basic scientific concepts like the "I, We, You" technique which is very present in our current education system (Davis \& Smithey, 2009). Inquiry and STEM education are closely related and dependent on each other. Inquiry is about giving precedence to students' findings and allowing them to present them to their learning community in order to develop their understanding of the natural world. Inquiry-based learning is important to science education because finding evidence for scientific concepts builds a strong foundational knowledge about the world. Inquiry can be promoted in science easily due to the fact that it has an explorative nature., (Beyer and Davis, 2008). According to Minner (2010), In order to promote successful STEM education, teachers need to give their students rich experiences through meaningful real world observation, hands-on learning, and peer discussion in order to strengthen their scientific conceptualization. Minner 
(2010) believes that schools and teachers that provide this experience can become capable of producing a much more innovative generation of students, thus impacting the future of STEM.

For the purpose of this study, diversity is defined as racially or ethnically dissimilar. According to Robert Geier (2008) from the Journal of Research in Science Teaching, The science education community understands that diverse learners populate urban areas, however, the research of this group is deficient. Likewise, teachers understand that students bring varied viewpoints to the classroom but are unsure of how to utilize this diversity to enhance inquiry learning outcomes (Davis \& Smithey, 2009). Efforts need to be made that support changing instruction toward an inquiry-based instruction model in order to utilize diversity within the classroom and create better prepared communities (Geier, 2008).The amount of inquiry-based scientific exposure is pertinent to the the success seen from students in science lessons (Geier, 2008). Portland Public Schools expounds a district-wide definition of underserved student population as a combination of students with limited english proficiency, those in special education, and those of races and ethnicities other than caucasian. Within elementary schools in Portland Public schools, 33.7\% of the population is described as underserved. In Oregon, Title I schools with students of color are " $1.48 \%$ more likely than [caucasian] students to have $50 \%$ or more of their core courses taught by [inexperienced or new teachers]". Students who live in poverty are $10 \%$ more likely to have $50 \%$ of their classes taught by inexperienced or new teachers (Oregon Department of Education, 2017). These statistics unveil that over 11\% of students represented within a given school's population are $50 \%$ more likely to have their classes instructed by inexperienced or new teachers. What this means for students is that new and inexperienced teachers tend to be less seasoned in STEM subjects, which can become evident 
through the lessons they teach (Fogleman, 2010). In fact, teachers who had previously been taught STEM lessons are found to be more capable of incorporating meaningful inquiry into their lessons to enhance students' concept knowledge (Fogleman, 2010). In Fogleman's (2010) study, there was a $38 \%$ improvement in students science comprehension with the most experienced teacher and compared to students taught by least experienced teacher. Suggesting that not only is the curriculum important but the experience had by the teacher is pertinent to students science comprehension.

Portland public schools can shed light on the effects of diversity on science achievement in urban areas which still can be found as a primary issue in the study of science education (Geier, 2008). Increased student diversity allows access to multiple perspectives; inquiry based learning is strengthened by developing creative solutions to scientific problems. Therefore, understanding the role of diversity to support inquiry based learning could provide education with a signified strategy to improve scientific education.

This study is intended to give insight into methods of STEM teaching, inquiry based learning, and diversity in schools by initiating a conversation about diversity and inquiry in STEM education, specifically in the Portland area. I will review schools that have focused on inquiry-based STEM methods with a diverse student body. By investigating what teachers and schools are doing to build strong STEM programs and how they expect their actions to produce a better equipped scientific community, we can provide tools for local educators to better inform teaching strategies for successful STEM outcomes.

\section{STEM Education with Inquiry}


Schools that apply inquiry-based learning strategies are finding enhanced student comprehension of science concepts (Fogleman, 2010). Students who learn through inquiry become active and reflective learners in their learning community (Fogleman, 2010). Inquiry-based learning begins by identifying existing knowledge which varies based on student perspectives. When students engage in scientific discussion with their peers, they connect ideas with evidence and reasoning so that they learn not only that something happens but why and how that something happens (Beyer and Davis, 2008). Beyer and Davis (2008) from The Journal of the Learning Sciences, suggest that scientific inquiry is crucial to creating foundational scientific conceptualization (such as proficiency in life, earth, and physical sciences) in early science education.

Science is a branch of knowledge that seeks to describe and understand the natural world. Science in elementary curriculum requires both conceptual knowledge as well as scientific practices. Successful STEM programs see science education as "way of knowing and doing," in other words focus on the method of acquiring knowledge (Beyer and Davis, 2008). Science education in elementary schools requires the students to be both mentally and physically engaged for assimilation of new information and concepts (Minner, 2010). The mental and physical attention of the students occurs when students are given responsibility for their own learning. Successful student engagement incorporates responsibility, active thinking, and motivation (Minner, 2010). These three imperative factors allow the learner to create "evidence-based explanations" that encourage the application of scientific practices Beyer and Davis, 2008). Evidence-based explanations are foundational to inquiry-based science education and contribute to the learner's interpretation of scientific concepts and procedures. 
Teachers are motivated to use inquiry-based techniques to teach science education because of the rich understanding learners' gain from inquiry lessons. Tactics that many successful teachers use are activities that initiate students understanding such as facilitating peer conversations, conducting investigations, and encouraging evidence-based explanations (Fogleman, 2010). The scientific explanation consists of creating a claim, providing evidence, and developing a reason or explanation (Beyer and Davis, 2008). These features of a classroom inquiry supplement group discussion and investigation creating the basic scientific method. These features are refined into asking scientific questions, constructing explanations with evidence, and communicating and justifying reasoning (Davis and Smithey, 2009). Inquiry-based learning is strongly emphasized as not only because it results in increased engagement and interest in science but, more importantly, as the understanding of how to construct a verifiable explanation to create scientific content knowledge.

\section{How does Diversity Influence Learning Outcomes?}

[Diversity is a key variable in inquiry education due to the fact that it allows for more perspectives within the student findings of STEM lessons. According to Patricia Gurin from the Journal of Social Issues (2004), Not only are students more motivated to work and interact in diverse environments but they are better equipped to "participate in a heterogeneous and complex society." Students from different backgrounds and cultures naturally view the world differently from one another due to variations in culture, personal history, and experiences. Creating a classroom atmosphere that includes a broad set of student experiences, enhanced through the inclusion of students of varying races and ethnicities creates a culture of cognitive growth. When the individual students "encounter experiences and demands that they cannot 
completely understand or meet," they then "must work to comprehend" and assimilate the new concepts (Gurin, 2004) It is evident that diversity is key in education for extracting varying perspectives. However, in PPS only $43 \%$ of the student population are people of color and among teachers only $19 \%$ are people of color. This stark difference is important to what is happening in Portland public schools and the shift that is being made.

\section{What is Happening in Portland Public Schools?}

Schools in Portland that that have included an explicit focus in their school's mission to implement strong STEM education programs include, but are not limited to,

Boise-Eliot/Humboldt school located in Grant district, Vernon School located in Madison district and Woodlawn school located in Roosevelt district. According to Portland public schools these specific schools define their philosophies as STEM-based. They lead by example with school gardens (hands-on learning spaces), STEM investment plans, STEM rich extracurricular programs, and STEM-based teaching pedagogies. Portland Public schools is using STEM to provide exceptional and lasting inquiry-based science education. This analysis of these select Portland Public schools will synthesize information about school diversity, test scores from 2013 and 2014 and the STEM strategies being taken compared to Rosa Parks K-5 and King K-8 who have similar diversity figures but are not implementing STEM initiatives (Table 1 1). All of the information about the following schools has been found from Portland Public Schools website through school pages, charts, and data collected by PPS. 
Diverse, Inquiry-based Science Education in Portland

Table 1: Diversity measures of 5 PPS Elementary Schools

\begin{tabular}{|c|c|c|c|c|c|c|c|c|c|c|}
\hline \multirow[t]{2}{*}{ School } & \multirow[t]{2}{*}{ District } & \multicolumn{8}{|c|}{ Percentage of Race/Ethnicity in School (as of 2016-2017 School Year) } & \multirow[b]{2}{*}{$\begin{array}{l}\text { Free/ } \\
\text { Reduced } \\
\text { Lunch }\end{array}$} \\
\hline & & Latino & $\begin{array}{l}\text { African } \\
\text { America } \\
n\end{array}$ & $\begin{array}{l}\text { Asian } \\
\text { American }\end{array}$ & $\begin{array}{l}\text { Native } \\
\text { America } \\
\text { n }\end{array}$ & $\begin{array}{l}\text { Pacific } \\
\text { Islande } \\
\mathbf{r}\end{array}$ & White & $\begin{array}{l}\text { Multi- } \\
\text { ethnic }\end{array}$ & $\begin{array}{l}\text { Total \# } \\
\text { students }\end{array}$ & \\
\hline $\begin{array}{l}\text { Boise-Eliot } \\
\text { /Humboldt }\end{array}$ & $\begin{array}{l}\text { Jefferson } \\
\text { /Grant }\end{array}$ & $12.20 \%$ & $59 \%$ & $2.40 \%$ & $1.50 \%$ & $0.20 \%$ & $\begin{array}{r}15.60 \\
\%\end{array}$ & $9 \%$ & 532 & $58.60 \%$ \\
\hline Vernon & $\begin{array}{l}\text { Jefferson } \\
\text { /Madison }\end{array}$ & $13.20 \%$ & $22.50 \%$ & $2.30 \%$ & $0.20 \%$ & $0.40 \%$ & $\begin{array}{r}50.30 \\
\%\end{array}$ & $11 \%$ & 471 & $28.50 \%$ \\
\hline Woodlawn & $\begin{array}{l}\text { Jefferson } \\
\text { /Rooseve } \\
\text { lt }\end{array}$ & $21.90 \%$ & $40.90 \%$ & $0.90 \%$ & $0.60 \%$ & $2.90 \%$ & $\begin{array}{r}25.10 \\
\%\end{array}$ & $7.60 \%$ & 342 & $44.40 \%$ \\
\hline $\begin{array}{l}\text { Rosa } \\
\text { Parks }\end{array}$ & $\begin{array}{l}\text { Roosevel } \\
\mathrm{t}\end{array}$ & $24.20 \%$ & $47.00 \%$ & $2.30 \%$ & $0.70 \%$ & $1.00 \%$ & $\begin{array}{r}13.40 \\
\%\end{array}$ & $\begin{array}{r}11.40 \\
\%\end{array}$ & 298 & $79.20 \%$ \\
\hline MLK Jr & $\begin{array}{l}\text { Jefferson } \\
\text { /Grant }\end{array}$ & $28.50 \%$ & $40.70 \%$ & $1.80 \%$ & $0.50 \%$ & $0.50 \%$ & $\begin{array}{r}13.00 \\
\%\end{array}$ & $\begin{array}{r}15.00 \\
\%\end{array}$ & 386 & $61.10 \%$ \\
\hline \begin{tabular}{|l} 
All PPS \\
2016
\end{tabular} & & $16.30 \%$ & $9.70 \%$ & $7.20 \%$ & $0.70 \%$ & $0.80 \%$ & $\begin{array}{r}55.80 \\
\%\end{array}$ & $5.9 \%$ & 49189 & $27.30 \%$ \\
\hline
\end{tabular}

\section{Portland Public Schools with STEM Initiatives:}

\section{Boise-Eliot/Humboldt:}

Boise-Eliot/Humboldt (BEH) PK-8 represented a total of $43 \%$ of the school population meeting or exceeding the standardized math test. Overall from 2013 to 2014 Asian Americans' total math score improved by 7\%; Caucasians' total math score improved by $1 \%$; and African Americans' total math score decreased by 4\%. The percentage of the school, broken down by major races and ethnicities, is represented by $75 \%$ of Asians meeting and exceeding math standards; $73 \%$ of caucasians meeting and exceeding math standards and $29 \%$ meeting and exceeding science standards; $37 \%$ of African Americans meeting and exceeding both math and 
science standards; and 30\% hispanics meeting and exceeding math standards and 14\% meeting and exceeding science standards.

The Boise-Eliot/Humboldt student body consists of 532 learners. Of the 532 students, 12.2\% are Latino or Hispanic, 59\% are African American, $2.4 \%$ are Asian, $1.5 \%$ are Native American, 9\% are multiple races and 15.6\% are Caucasian (table 1). In correspondence to these figures, $58.6 \%$ of the entire student body receives free or reduced school lunch.

The school wide pedagogy at Boise-Eliot/Humboldt PK-8 is a STEAM-based school that strives to celebrate diversity and responsible citizenship through STEM education. BEH is committed to developing a community where students of all kinds can experience rigorous learning opportunities that challenge them to critically think about the local, national, and global community. The curriculum shift implemented by BEH is intended to develop the student body's content knowledge through inquiry projects, STEM education, and an integration of interdisciplinary units. Diverse perspectives serve as a foundation in which the students build new knowledge through inquiry-based lessons. BEH has a strong emphasis on diversity due to the population being served. To promote a rich science education, BEH has implemented a mentorship for the students with mentors that reflect the student's' ethnicity ?to encourage the connection to STEM subjects and the students at BEH. The practice of mentorships is key to inquiry based learning because students model scientific behavior and it provides a teaching (by the mentor) and learning (by the the mentee) space that fosters deep learning by encouraging thoughtful reasoning with peers. Connecting students with mentors of a similar ethnicity allows students to relate information ?? . Additionally, BEH implements STEM Saturday, schoolwide 
Diverse, Inquiry-based Science Education in Portland

13

engineering challenges, and teacher development to support students' and teachers' STEM understanding to promote a smooth shift towards a STEM curriculum.

\section{Woodlawn:}

Woodlawn PK-8 represents $42 \%$ of the school population meeting or exceeding the standardized math test. Overall from 2013 to 2014, Caucasians' total math score improved by 18\%; Hispanics' total math score improved by $12 \%$; Pacific Islanders' total math score improved by $10 \%$; and African Americans' total math score improved by $5 \%$. The percentage of the school is broken down by major races and ethnicities, is represented by $67 \%$ of caucasians meeting and exceeding both math and science standards; $44 \%$ of African Americans meeting and exceeding math standards and 44\% meeting and exceeding science standards; $50 \%$ of Pacific Islanders meeting and exceeding math standards; and $32 \%$ of Hispanics meeting and exceeding math standards and 64\% meeting and exceeding science standards.

Woodlawn PK-8 school is made up of 342 students. Of the student population, $12.2 \%$ are Latino or Hispanic, $40.9 \%$ are African American, $0.9 \%$ are Asian, $0.6 \%$ are Native American, $2.9 \%$ are Pacific Islander, 5.9\% are multiple races, and 55.8\% are Caucasian (table 1 ). Of this school representation, $44.4 \%$ receive free or reduced school lunches.

The STEM Mission, with the additon of arts integration, at Woodlawn uses a planetary theme within their school to prepare the students to be part of a competitive workforce with the foreseen growth of STEM related jobs. Woodlawn is doing so by connecting their students with experts and organizations within the local, national, and global community. Giving the students at Woodlawn the responsibility for their own learning is key to engaging them in inquiry-based STEM learning. It is clear that Woodlawn does so by implementing a theme that interests all the 
students and engages them in their own learning. They chose to use a planetary theme because it is exciting to students and can encourage further study with partners such as OMSI and the Viking Mars Mission Project. Examples of connecting other science topics to the planetary themes are examining weather on other planets during a weather unit, examining how water changes a planet during an Earth systems unit, and examining a sustainable biosphere during an ecosystem unit. In addition to planetary links within the whole curriculum at Woodlawn PK-8, a STEAM Night is held yearly at the end of the school year. This night is where the students from all grades display their science progress from the year through art projects, interactive engineering challenges, and science demonstrations. Additionally, a keynote speaker is invited to speak about STEM topics and everyone is invited to enjoy a meal together. This event is a night where Woodlawn assembles to interact and learn with the community and teach one another about science.

\section{Vernon}

Vernon PK-8 represents $45 \%$ of the school population meeting and exceeding the standardized math test. Overall from 2013 to 2014 Caucasians' total math score increased by 1\%; African Americans' total math score decreased by 9\%; Hispanics' total math score decreased by 12\%; and Asian Americans' total math score decreased by 15\% from 2012 to 2014.

The Vernon PK-8 student population consists of 471 individuals. Of these students, 13.2\% are Latino or Hispanic, 22.5\% are African American, 2.3\% are Asian, $0.2 \%$ are Native american, $0.4 \%$ are Pacific Islander, $11 \%$ are multiple races and 50.3\% are Caucasian. 28.5\% of this student body receives free or reduced lunches (table 1). 
Vernon school is an International Baccalaureate (IB) school that is formed by units developed by teachers. By nature, these units are interdisciplinary with arts, social science, and STEM subjects. They are written to include significant connections to STEM themes. Vernon incorporates lego robotics, online science subscriptions, STEAM night, a STEAM Fair, and a STEAM Olympics where the classrooms competes with each other through inquiry and hands-on learning. In addition, Vernon supports its students' scientific inquiry with a garden for cooking, agriculture connections, and other earth systems. Through the many extracurricular programs that Vernon provides students are given responsibility for the learning and assimilate knowledge within peer groups.

\section{Portland Public Schools without STEM Initiatives:}

\section{Rosa Parks:}

Rosa Parks K-5 school renders a total of $27 \%$ of the entire school meeting and exceeding math standardized tests. Overall from 2013 to 2014 school year, African American students’ math scores decreased by almost 20\%, Hispanic students' test scores decreased by nearly $15 \%$, and Caucasian students' test scores decreased by $20 \%$.

The population at Rosa Parks K-5 is represented by a total of 298 students. Of this 298 , 24.2\% are Latino or hispanic, 47\% are African American, 2.3\% are Asian American, 0.7\% are Native American, $1 \%$ are Pacific Islanders, 13.4\% are Caucasian, and $11.4 \%$ are multiethnic. Among the Rosa Parks student body 79.2\% receive free or reduced lunches (table 1).

King: 
At Martin Luther King Jr. (referred to as King) only $26 \%$ of the student body meets or exceeds math standardized tests. As a total, African American students' test scores decreased by 4\%, Hispanic students' scores increased by 7\%, Multiethnic students' test results increased by $1 \%$, and Caucasian students' scores decreased by $14 \%$.

The total population at King K-8 is 386 students. Of these students, $28.5 \%$ are Latino or Hispanic, $40.7 \%$ are African American, $1.8 \%$ are Asian American, $0.5 \%$ are Native American, $0.5 \%$ are Pacific Islander, $13 \%$ are Caucasian, and $15 \%$ are multiethnic. Additionally, $61.1 \%$ of the King students receive free or reduced lunches (table 1).

\section{Discussion}

The STEM positive position taken by Woodlawn, Vernon, and Boise-Eliot/Humboldt schools has created opportunity for many students of varying backgrounds to explore scientific subjects. The intention of giving specific attention to these aspects of education is to deepen learning over time. These movements in Portland Public schools have allowed for more STEM instructional time, better prepared teachers with more opportunities for STEM training courses, and more resources available to the schools. It is evident that there are huge disparities between the schools with STEM initiatives and the schools without. The schools with STEM curriculums see a score of approximately $43.3 \%$ of their students meeting and exceeding math scores compared to Rosa Parks and King elementary that only see approximately $26.5 \%$ of the students meeting and exceeding standardized math scores. Not only is this difference extreme but it sheds light on the huge value of including is inquiry-based STEM education that offers interdisciplinary learning that enhances sense-making. It is important that schools with racially 
diverse students access experienced teachers and resources because people of color face a one in three chance of not graduating high school in comparison to the 1 in 14 probability of a Caucasian student (Oregon Department of Education, 2017). Vernon, Woodlawn, and BEH are addressing this is by implementing strong STEM pedagogies within their curriculums. While Vernon's racially and ethnically diverse population did not show scores similar to that of BEH and Woodlawn, they did show more achievement overall compared to Rosa Parks and King. This is inconsistent with my expectations, though indicates that inquiry-based STEM education varies cases by case and can be influenced by teaching styles, STEM and inquiry exposure, and student engagement. Nevertheless, BEH is bridging this gap between student and teacher ethnic representation by providing their students models of success through mentorship. The mentorship is in place to create positive relationships with STEM. According to the Oregon Department of Education (2017), African American students who were taught math by an African American Teacher saw a 2 to 4 percentile increase on their standardized math score. In Portland Public schools there is approximately a 30\% gap between students of color and teachers of color. In Portland Public schools, $43 \%$ of the student population are people of color in comparison to only $19 \%$ of Portland teachers are people of color. Meaning that many students are unable to make a similar relationship or connection to STEM subjects because they do not relate to the instructor. This shift in BEH is positive to the STEM competencies of its students and also positive for the overall desire to learn from its students. According to the Oregon Department of Education (2017), African American students in 3rd, 4th, and 5th grades have greater probability of finishing high school if they were taught by an African American teacher. The dropout rate is diminished by $39 \%$. Not only are students of color seeing a positive change 
in their STEM competency but are also seeing better graduation rates. Diverse learners in an urban community are underserved by the low ratio of teachers of color. However, with the mentorship that $\mathrm{BEH}$ is implementing, may bridge the gap because students of color are given the opportunity to relate closely to peers as models with strong scientific understanding. However, the decrease in scores in African American population among student bodies continues to be a conclusion.

As the students begin to build relationships with STEM they also explore science phenomena through inquiry and scientific methods. With the presence of science content comes the engagement in the investigation and the active thinking that promotes responsibility and motivation for learning (Minner, 2010). Not only does this support autonomous learning but also retention. According to Minner (2010), 55\% of her studies have shown that students that learned in classrooms with high levels of inquiry employed did significantly better than those who did not. Additionally, those who learned through inquiry with high levels of student responsibility and hands-on activities experienced significantly higher conceptual understanding of STEM topics than those who did not (Minner, 2010). By evidence of test scores, Woodlawn school is seeing upward trends in the students' STEM competency with increased scores from all students of color and non color. Clearly, the interdisciplinary approach of the planetary school is allowing students to build the initial, fundamental science knowledge. By requiring students to constantly consider how the planets are affected and involved in the curriculum encourages them to collaborate with their peers, construct usable knowledge by linking ideas, and creating relations between everyday and science (Geier, 2008). By definition, this is inquiry and Woodlawn is 
supporting it in a natural way that excites students and motivates them to create their own learning.

In this study, literature regarding the benefits of inquiry-based learning, STEM education, and racially diverse learning environments were evaluated. It is clear that students of color are underserved in the educational system, nonetheless STEM subjects. In the Portland schools that have been analyzed for this study, it is clear that there are huge disparities between schools and within the schools. It is very visible that Caucasian students in this sample of Portland schools tend to score higher than African American students and Hispanic students. Yet, it is also evident that more of the students within schools with STEM focuses score higher than those in the schools without STEM focuses and are seeing almost a $20 \%$ difference in success. For the purposes of this study, inquiry-based STEM education within diverse elementary schools is successful and is showing it with a $20 \%$ gain in successful student test scores. The STEM movements that BEH, Woodlawn, and Vernon are making to support students' of color education is making evident that it is beneficial and necessary to creating a responsible and responsive generation. Future research of inquiry based STEM education in racially diverse schools needs to include classroom observation and interviews. In graduate studies, I hope to pursue this topic in practicum to learn how diverse students are learning STEM, what teachers are doing to support diverse STEM education, and what administration is doing to support teachers who are implementing inquiry-based and diverse STEM education. To expand upon this research it is necessary to observe racially and ethnically diverse students within rich STEM programs. I imagine through observation, it will become clear what techniques teachers are using and how students are becoming motivated to assimilate STEM concepts. Additionally, future 
research could explore the ways teachers are trained to support inquiry and STEM education and how they assess their students understanding. Future research could delve into how to measure understanding that students gain from inquiry lessons and how to evaluate the understanding through interviews, testing, and observation of learning. This will not only give information about what the students are learning but how they are assimilating STEM concepts and how it is being delivered by the teachers. It is evident that students experience rich conceptual understanding from inquiry lessons and this topic could take a researcher in many directions for educational research. In the research conducted, it is clear that inquiry-based STEM education supports more students scientific and mathematical conceptualization through student interaction and motivation. Furthermore, these findings shed light on how diverse learners can be further supported and what actions contribute to positive learning outcomes for all students.

\section{Conclusion}

In conclusion, this study has attempted to look into Portland Public schools that focus on STEM in their mission and learn how the schools are supporting inquiry-based STEM education in racially and ethnically diverse classrooms through an investigation that focused on what promotes science inquiry and mathematical sense-making, how teachers are embracing it, and if students are motivated by inquiry. Inquiry-based learning is a substantial tool to empowering students to create their own understanding of STEM concepts and its relationship to the natural world. Three schools including Boise-Eliot/Humboldt, Woodlawn, and Vernon were investigated due to the strong presence of STEM initiatives within their curriculums and compared to two 
Diverse, Inquiry-based Science Education in Portland 21

school with comparable diversity figures. The goal of this study was to better understand methods of STEM teaching through inquiry-based learning and to generate conversation about Portland's inquiry-based learning in diverse communities and how it can positively affect the students scientific and mathematical comprehension. 
Diverse, Inquiry-based Science Education in Portland

22

\section{References}

Beyer, C. J., \& Davis, E. A. (2008). Fostering Second Graders Scientific Explanations: A Beginning Elementary Teachers Knowledge, Beliefs, and Practice. Journal of the Learning Sciences, 17(3), 381-414. doi:10.1080/10508400802222917

Boise-Eliot/Humboldt PK-8 School. (n.d.). Retrieved July 31, 2017, from https://www.pps.net/domain/597

Curry-Stevens, A., Cross-Hemmers, A., \& T. (2010). Communities of Color in Multnomah County: An Unsettling Profile [Scholarly project]. In Portland State University PDXScholar. Retrieved from http://pdxscholar.library.pdx.edu/cgi/viewcontent.cgi?article=1091\&context=socwork_fac

Chief Education Office. (2017, June). 2017 Educator Equity Report. Retrieved July 31, 2017, from http://education.oregon.gov/portfolio/2017-educator-equity-report-2/

Davis, E. A., \& Smithey, J. (2009). Beginning teachers moving toward effective elementary science teaching. Science Education, 93(4), 745-770. doi:10.1002/sce.20311

Dekorver, B. K., Choi, M., \& Towns, M. (2016). Exploration of a Method To Assess Children's Understandings of a Phenomenon after Viewing a Demonstration Show. Journal of Chemical Education, 94(2), 149-156. doi:10.1021/acs.jchemed.6b00506

DeSilver, D. (2017, February 15). U.S. students' academic achievement still lags that of their peers in many other countries. Retrieved July 31, 2017, from http://www.pewresearch.org/fact-tank/2017/02/15/u-s-students-internationally-math-scie nce/

Geier, R., Blumenfeld, P. C., Marx, R. W., Krajcik, J. S., Fishman, B., Soloway, E., \& Clay-Chambers, J. (2008). Standardized test outcomes for students engaged in inquiry-based science curricula in the context of urban reform. Journal of Research in Science Teaching, 45(8), 922-939. doi:10.1002/tea.20248

Green, E. (2014, July 23). Why Do Americans Stink at Math? Retrieved August 07, 2017, from https://www.nytimes.com/2014/07/27/magazine/why-do-americans-stink-at-math.html 
Diverse, Inquiry-based Science Education in Portland

23

Gurin, P., Nagda, B. (., \& Lopez, G. E. (2004). The Benefits of Diversity in Education for Democratic Citizenship. Journal of Social Issues, 60(1), 17-34. doi:10.1111/j.0022-4537.2004.00097.x

Fogleman, J., Mcneill, K. L., \& Krajcik, J. (2010). Examining the effect of teachers adaptations of a middle school science inquiry-oriented curriculum unit on student learning. Journal of Research in Science Teaching, 48(2), 149-169. doi:10.1002/tea.20399

Jolly, J. L. (2009). Historical Perspectives: The National Defense Education Act, Current STEM Initiative, and the Gifted. Gifted Child Today, 32(2), 50-53. doi:10.4219/gct-2009-873

Kang, N., Orgill, M., \& Crippen, K. J. (2008). Understanding Teachers' Conceptions of Classroom Inquiry With a Teaching Scenario Survey Instrument. Journal of Science Teacher Education, 19(4), 337-354. doi:10.1007/s10972-008-9097-4

Lloyd | February 3, 2016 Print article, C. (2016, February 3). Why our smartest students are failing math. Retrieved August 07, 2017, from https://www.greatschools.org/gk/articles/why-americas-smartest-students-fail-math/

Minner, D. D., Levy, A. J., \& Century, J. (2010). Inquiry-based science instruction-what is it and does it matter? Results from a research synthesis years 1984 to 2002. Journal of Research in Science Teaching, 47(4), 474-496. doi:10.1002/tea.20347

Portland Public Schools (2016, October 3). Enrollment of Underserved Groups [Chart]. In Portland Public Schools. Retrieved August 7, 2017, from https://www.pps.net/cms/lib/OR01913224/Centricity/Domain/207/Enrollment\%20of\%20U nderserved\%20Groups_2016.pdf

Portland Public Schools. (n.d.). Portland Public Schools Racial Educational Equity Policy. Portland Public Schools Racial Educational Equity Policy. Retrieved from https://docs.google.com/viewerng/viewer?url=https://www.pps.net//cms/lib/OR01913224/C entricity/Domain/51/RACIALEducation_Equity_Policy.pdf.

Portland Public Schools. (2017). Free and Reduced Meal Eligibility (2016-17 SY) [Digital image]. Retrieved from 
Diverse, Inquiry-based Science Education in Portland

24

https://www.pps.net/cms/lib/OR01913224/Centricity/Domain/207/Enrollment_by_Meal_E1 igibility_2016-17.pdf

Portland Public Schools. (2016). Portland Public Schools October 3rd, 2016 Enrollment - Summary Comparison [Digital image]. Retrieved from https://www.pps.net/cms/lib/OR01913224/Centricity/Domain/207/EnrollmentbyProgramTy pe_Grade_RaceEthnicity_2016.pdf

Portland Public Schools. (2016). Portland Public Schools Enrollment Summary by Race and Ethnicity, October 2016 [Digital image]. Retrieved from https://www.pps.net/cms/lib/OR01913224/Centricity/Domain/207/PPS\%20Enrollment\%20 by\%20Race\%20Ethnicity\%202016.pdf

PPS Research. (n.d.). 2014 Assessment Overview: Boise-Eliot/Humboldt Grades 3-8 [PDF]. Portland: Portland Public Schools.

PPS Research. (n.d.). 2014 Assessment Overview: Woodlawn PK-8 Grades 3-8 [PDF]. Portland: Portland Public Schools.

PPS Research. (n.d.). 2014 Assessment Overview: Vernon PK-8 Grades 3-8 [PDF]. Portland: Portland Public Schools.

PPS Research. (n.d.). 2014 Assessment Overview: Rosa Parks K-5 Grades 3-5 [PDF]. Portland: Portland Public Schools.

PPS Research. (n.d.). 2014 Assessment Overview: King K-8 Grades 3-8 [PDF]. Portland: Portland Public Schools.

STEM Investment Plan (Rep.). (2013). Portland, OR: Boise-Eliot/Humboldt .

Vernon School. (n.d.). Retrieved from https://www.pps.net/domain/2630

Woodlawn PK-5 School. (n.d.). Retrieved July 31, 2017, from https://www.pps.net/domain/948

Woodlawn. (n.d.). Flyer for STEAM 2017 [PDF]. Portland .

Woodlawn. (n.d.). NGSS Connection Between Grades [PDF]. Portland . 
Diverse, Inquiry-based Science Education in Portland 25

Woodlawn. (n.d.). STEAM Proposal- Welcome to Woodlawn- A Planetary School [PDF]. Portland Woodlawn. (n.d.). Woodlawn NGSS-Kindergarten 2015-2016 [PDF]. Portland .

Woodlawn. (n.d.). 2nd Grade Woodlawn NGSS 2015-2016 [PDF]. Portland .

Woodlawn. (n.d.). 5th Grade Woodlawn NGSS 2015-2016 [PDF]. Portland

Yosso, T. J. (2005). Whose culture has capital? A critical race theory discussion of community cultural wealth. Race Ethnicity and Education, 8(1), 69-91. doi:10.1080/1361332052000341006 